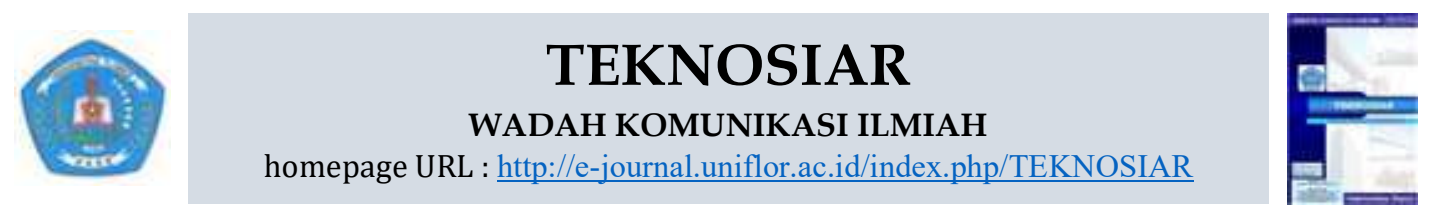

\title{
Analisis Penggunaan Pelat Beton Bondek Pada Struktur Lantai Gedung Puskesmas Kota Ende
}

\author{
Maria Alfiani Weli ${ }^{1}, *$ Yohanes Laka Suku², Veronika Miana Radja ${ }^{3}$ \\ ${ }^{1}$ Alumni Program Studi Teknik Sipil, Fakultas Teknik, Universitas Flores, Ende \\ ${ }^{2,3}$ Program Studi Teknik Sipil, Fakultas Teknik, Universitas Flores, Ende \\ *Corresondence e-mail: mayokonco@yahoo.co.id
}

Received: 28-03-2021 Revised:10-04-2021 Accepted: 25-04-2021.

\begin{abstract}
The floor structure of the Ende City Health Center Building that has been worked on uses conventional plates with a plate thickness of $12 \mathrm{~cm}$ and $10 \mathrm{~cm}$. One method of plate work that is currently being developed is to use bondek. Bondek plate is a combination plate that uses bondek as a substitute for positive moment reinforcement, as well as already functioning as under plate and floor formwork. This study aims to check the strength of the floor slabs when using bondek with the same workload. The data used in this study are secondary data in the form of work images, Budget Plans and Work Plans and Conditions. The results showed that the moment capacity on the plate $12 \mathrm{~cm}$ and $10 \mathrm{~cm}$ using bondek type $W-1000$ with a thickness of $0.65 \mathrm{~mm}, 0.70$ $\mathrm{mm}$ and $1.00 \mathrm{~mm}$ is greater than the moment capacity of conventional reinforced concrete slabs installed. So again, the analysis was carried out using smaller plate sizes, including $11 \mathrm{~cm}, 10 \mathrm{~cm}$ and $9 \mathrm{~cm}$ for $12 \mathrm{~cm}$ plates, while $9 \mathrm{~cm}, 8 \mathrm{~cm}$ and $7.5 \mathrm{~cm}$ for $10 \mathrm{~cm}$ plates. From the analysis results obtained twenty two (22) plates in a safe condition because the plate moment capacity using bondek is greater than the moment capacity of conventional reinforced concrete slabs installed, as well as meeting the allowable deflection limit requirements. Meanwhile, two (2) plates are in an unsafe state because they do not meet the allowable deflection limit requirements.
\end{abstract}

Keywords : Conventional Concrete Slab, Bondek Concrete Slab, Building Floor

\begin{abstract}
ABSTRAK
Struktur lantai Gedung Puskesmas Kota Ende yang telah dikerjakan menggunakan pelat konvensional dengan ketebalan pelat $12 \mathrm{~cm}$ dan $10 \mathrm{~cm}$. Salah satu metode pekerjaan pelat yang tengah berkembang saat ini adalah menggunakan bondek. Pelat bondek merupakan pelat kombinasi yang menggunakan bondek sebagai pengganti tulangan momen positif, sekaligus sudah berfungsi sebagai bekisting bawah pelat dan lantai kerja. Penelitian ini bertujuan untuk mengecek kekuatan pelat lantai jika menggunakan bondek dengan beban kerja yang sama. Data yang digunakan pada penelitian ini ialah data sekunder berupa gambar kerja, Rencana Anggaran Biaya (RAB) dan Rencana Kerja dan Syarat (RKS). Hasil penelitian menunjukan kapasitas momen ada pada pelat $12 \mathrm{~cm}$ dan $10 \mathrm{~cm}$ yang menggunakan bondek tipe $W-1000$ dengan ketebalan 0,65 mm, 0,70 mm dan 1,00 mm lebih besar dari kapasitas momen pelat beton bertulang konvensional yang terpasang. Sehingga kembali dilakukan analisis menggunakan ukuran pelat yang lebih kecil antara lain $11 \mathrm{~cm}, 10 \mathrm{~cm}$ dan $9 \mathrm{~cm}$ untuk pelat $12 \mathrm{~cm}$, sedangkan $9 \mathrm{~cm}, 8 \mathrm{~cm}$ dan $7,5 \mathrm{~cm}$ untuk pelat $10 \mathrm{~cm}$. Dari hasil analisis diperoleh dua puluh dua (22) pelat dalam kondisi aman karena kapasitas momen pelat menggunakan bondek lebih besar dari kapasitas momen pelat beton bertulang konvensional yang terpasang, serta memenuhi syarat batas lendutan yang diijinkan. Sedangkan dua (2) pelat dalam keadaan tidak aman karena tidak memenuhi syarat batas lendutan yang diijinkan.
\end{abstract}

Kata kunci : Pelat Beton Konvensional, Pelat Beton Bondek, Lantai Gedung

TEKNOSIAR Volume 15, No.01, April 2021

p-ISSN 1907-5197 (versi cetak) e-ISSN 2721-2270 (versi online) 


\section{PENDAHULUAN}

Perkembangan teknologi dalam bidang konstruksi saat ini mengalami kemajuan yang sangat pesat, dimana dengan berbagai kondisi terus dilakukan upaya untuk meningkatkan kualitas dan kuantitas pekerjaan. Hal ini ditandai dengan hadirnya banyak teknologi baru yang diperkenalkan dan diaplikasikan pada bidang konstruksi untuk membuat proses pekerjaan menjadi lebih baik dari segi konstruksi struktur, cepat dalam waktu pelaksanaan dan murah dalam biaya pelaksanaannya. Tahap utama yang dilakukan pada pembangunan sebuah konstruksi gedung ialah perencanaan konstruksi. Tahap ini merupakan tahap pemilihan desain struktur dan bahan yang akan digunakan dalam pelaksanaan pekerjaan konstruksi bangunan tersebut. Suatu struktur bangunan dikategorikan baik jika strukturnya memenuhi persyaratan kekuatan, kestabilan dan kekakuan struktur (Suku \& Je, 2020). Syarat tersebut dapat terpenuhi jika komponen struktur di desain dengan baik. Komponen tersebut di antaranya adalah balok, kolom dan pelat lantai.

Salah satu kemajuan teknologi pada bidang konstruksi gedung adalah penggunaan pelat beton bondek pada struktur lantai untuk menggantikan pelat beton konvensional. Pelat beton bondek merupakan pelat kombinasi yang menggunakan bondek sebagai pengganti tulangan momen positif (tulangan bagian bawah) sekaligus berfungsi sebagai bekisting dan sebagai lantai kerja (Dewi Kusmila, 2018). Dengan menggunakan pelat bondek dapat mengurangi rembesan campuran beton sehingga Faktor Air Semen (FAS) tetap terjaga dan proses penguapan dapat berlangsung dengan baik untuk mencapai mutu beton yang direncanakan serta mendukung kekuatan struktur pelat.

Seiring dengan perkembangan teknologi telah banyak dijumpai bangunan-bangunan gedung bertingkat yang struktur lantainya menggunakan pelat beton bondek. Proyek konstruksi Pembangunan Gedung Puskesmas Kota Ende yang telah selesai dilaksanakan, struktur pelat lantai yang dikerjakan menggunakan pelat beton konvensional, dengan ketebalan pelat $12 \mathrm{~cm}$. Oleh sebab itu peneliti tertarik untuk melakukan analisis penggunaan pelat beton bondek pada Gedung Puskesmas Kota Ende dengan meninjau kekuatan dan kekauan struktur dari tiga ketebalan bondek yang berbeda tanpa mengurangi mutu dan kekuatan strukturnya berdasarkan gambar kerja yang sudah ada.

\section{TINJAUAN PUSTAKA}

Pelat merupakan salah satu elemen struktur horizontal yang dipengaruhi oleh panjang bentang dan beban yang bekerja padanya. Pelat juga merupakan salah satu elemen struktur yang lebih dominan memikul momen lentur dan gaya geser. Pada pelat lantai hanya diperhitungkan adanya beban tetap saja (penghuni, perabotan, berat lapis tegel, berat sendiri pelat) yang bekerja secara tetap dalam waktu lama. Sedangkan beban tak terduga seperti gempa, angin, getaran tidak diperhitungkan. (Dewi \& Kusmila, 2018)

Pelat lantai beton konvensional merupakan pelat lantai beton yang dibuat secara manual / konvensional tanpa menggunakan bahan pabrikasi. Analisis kapasitas momen pelat konvensional dilakukan dengan langkah perhitungan sebagai berikut:

a. Menghitung Luas Tulangan (As)

$$
\text { As } \quad=1 / 4 \cdot \pi \cdot \mathrm{d}^{2} \cdot(\mathrm{b} / \mathrm{s})
$$

b. Menghitung Rasio Tulangan $(\rho)$

$$
\begin{aligned}
& \rho \quad=A_{\mathrm{s}} /(\mathrm{b} . \mathrm{d}) \\
& \text { dengan syarat }: \rho_{\min } \leq \rho \leq \rho_{\text {maks }} \\
& \rho_{\min } \quad=\frac{1,4}{f y} \\
& \rho_{\mathrm{b}} \quad=0,85 \times \beta_{1} \times \frac{f^{\prime} c}{f y}\left(\frac{600}{600+f y}\right)
\end{aligned}
$$

TEKNOSIAR Volume 15, No.01, April 2021

p-ISSN 1907-5197 (versi cetak) e-ISSN 2721-2270 (versi online) 
$\rho_{\text {maks }} \quad=0,75 . \rho_{\mathrm{b}}$

Kontrol syarat :

$\rho_{\text {min }} \leq \rho \leq \rho_{\text {maks }}(\mathrm{OK})$

c. Menghitung Tinggi Beton Kekang (a)

$\mathrm{a}=\frac{\mathrm{A}_{s . f y}}{0,85 . f^{\prime} c . b}$

d. Menghitung Jarak Garis Netral (c)

$\mathrm{a}=\beta_{1} . \mathrm{c}$

$\mathrm{c}=\mathrm{a} / \beta_{1}$

e. Kontrol Regangan Leleh Baja $\left(\varepsilon_{s}\right)$

$\mathrm{c} / \mathrm{d}_{\mathrm{s}}=0,465>0,111$

$\varepsilon_{\mathrm{s}} \quad=\left(\frac{d-c}{c}\right) \cdot \varepsilon_{\mathrm{c}}$

f. Momen Nominal (Mn)

$\mathrm{Mn} \quad=\mathrm{A}_{\mathrm{s}} \cdot$ fy. $(\mathrm{d}-\mathrm{a} / 2)$

g. Momen Ultimit Ada $\left(\mathrm{MU}_{\mathrm{Ada}}\right)$

$$
\mathrm{MU}_{\mathrm{Ada}} \quad=\varnothing \cdot \mathrm{Mn}
$$

Pelat lantai bondek adalah pelat kombinasi yang menggunakan bondek sebagai pengganti tulangan momen positif (tulangan bagian bawah), sekaligus sudah berfungsi sebagai bekisting bawah pelat dan lantai kerja, sedangkan untuk tulangan momen negatif bisa menggunakan tulangan baja biasa atau menggunakan wiremesh. Komponen utama pelat beton bondek adalah pelat baja gelombang yang sering disebut bondek, wiremash dan beton (Dewi \& Kusmila, 2018). Untuk analisa perhitungan pelat lantai bondek menggunakan rumus dari American National Standards Institute (ANSI) / Steel Deck Institute 2011, yang dapat dilihat di bawah ini :

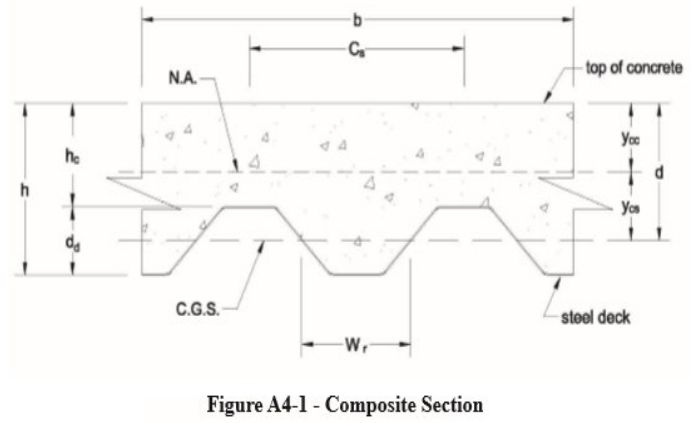

Gambar 1. Penampang Komposit Pelat Lantai Bondek

$\mathrm{d}=\mathrm{h}-\frac{1}{2} x$ tinggi gelombang

Lalu,

$\mathrm{hc}=\mathrm{h}-$ tinggi gelombang

$\mathrm{Ycc}=d\{\sqrt{2 \rho \mathrm{n}+(\rho \mathrm{n}) 2-\rho \mathrm{n}}\}<\mathrm{hc}$

Dimana $: \mathrm{n}=\frac{\text { Es }}{\mathrm{Ec}}$

$=\frac{E s}{0,043 \times(\mathrm{Wc})^{1,5} \times \sqrt{f^{\prime} c}}$

$\rho \quad=\frac{\text { As }}{(\mathrm{bxd})}$

Ycs $\quad=\mathrm{d}-$ Ycc

TEKNOSIAR Volume 15, No.01, April 2021

p-ISSN 1907-5197 (versi cetak) e-ISSN 2721-2270 (versi online) 
$\mathrm{Ic}=\frac{\mathrm{b}}{3 \mathrm{xh}} x \mathrm{Ycc}^{3}+$ As $\mathrm{x} \mathrm{Ycs} 2+\mathrm{Isf}$

Flexural Strength :

$$
\begin{aligned}
& \mathrm{My}=\frac{(f y \times \mathrm{Ic})}{(\mathrm{h}-\mathrm{Ycc})} \\
& \mathrm{Mru}=\emptyset \times \mathrm{My}
\end{aligned}
$$

\section{METODOLOGI PENELITIAN}

\section{Objek Penelitian}

Penelitian dilakukan pada struktur lantai Gedung Puskesmas Kota Ende yang bertempat di Jl. Kokos Raya (Perumnas) - Kel. Mautapaga - Kec. Ende Tengah. Gedung tersebut dibangun diatas lahan tanah berukuran $30 \mathrm{~m}$ x 22,8 m yang terdiri dari dua lantai dan satu lantai dengan luas $506 \mathrm{~m}^{2}$. Didirikan kokoh dengan struktur rangka beton bertulang serta menggunakan pelat lantai beton konvensional.

\section{Tahapan Analisis}

Tahapan analisis dimulai dengan menghitung kapasitas momen lentur dari pelat beton konvensional berdasarkan data dimensi yang sudah ada pada gambar kerja pembangunan Gedung Puskesmas Kota Ende. Setelah itu dilakukan analisis perencanaan pelat lantai beton dengan menggunakan pelat bondek berdasarkan momen ultimit yang telah dihitung dari pelat beton konvensional dengan tiga ketebalan bondek yang berbeda serta meninjau kekuatan dan kekakuan masing-masing.

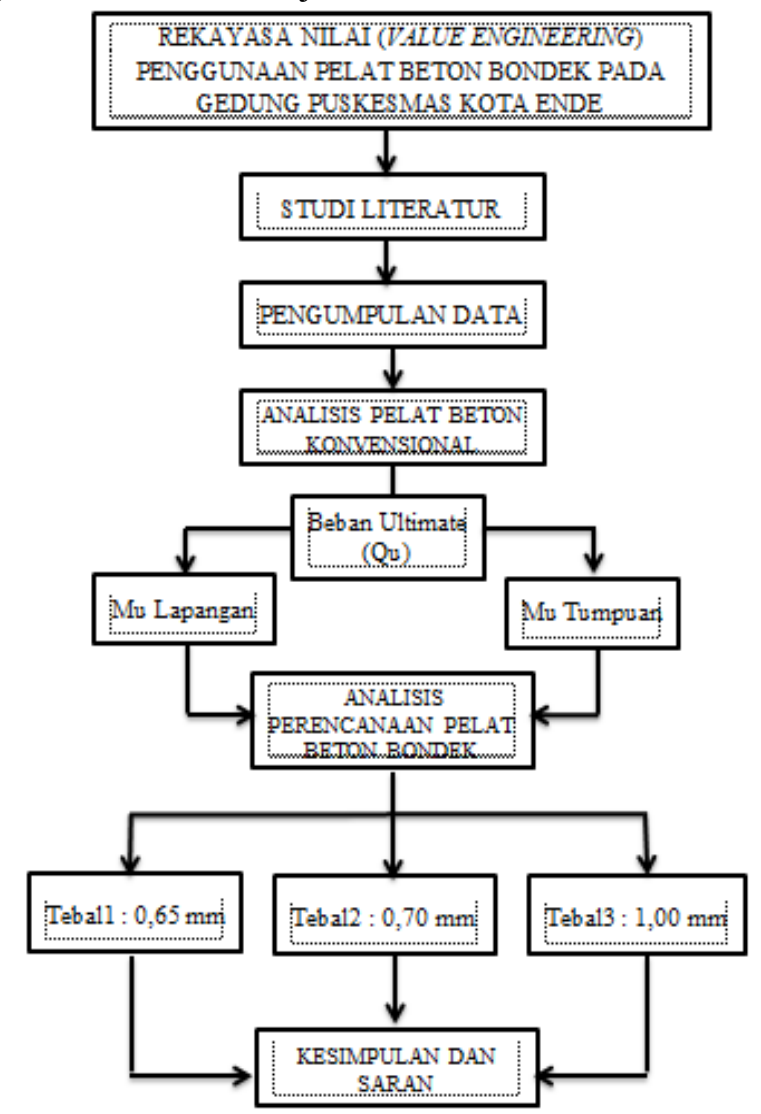

Gambar 2. Diagram Alir Penelitian

TEKNOSIAR Volume 15, No.01, April 2021

p-ISSN 1907-5197 (versi cetak) e-ISSN 2721-2270 (versi online) 
Maria Alfiani Weli1, Yohanes Laka Suku, Veronika Miana Radja

Analisis Penggunaan Pelat Beton Bondek Pada Struktur Lantai Gedung Puskesmas Kota Ende

\section{HASIL DAN PEMBAHASAN}

\section{Data Pelat}

Pelat yang digunakan pada pekerjaan pembangunan Gedung Puskesmas Kota Ende terbagi atas 2 ukuran yaitu $12 \mathrm{~cm}$ dan $10 \mathrm{~cm}$. Pelat dengan ukuran $12 \mathrm{~cm}$ difungsikan sebagai pelat lantai 2 sedangkan pelat berukuran $10 \mathrm{~cm}$ difungsikan sebagai pelat deck yang terdiri dari pelat satu arah (one way slab) dan pelat dua arah (two way slab) dengan detail penulangannya seperti tertera pada gambar 3 dan 4.

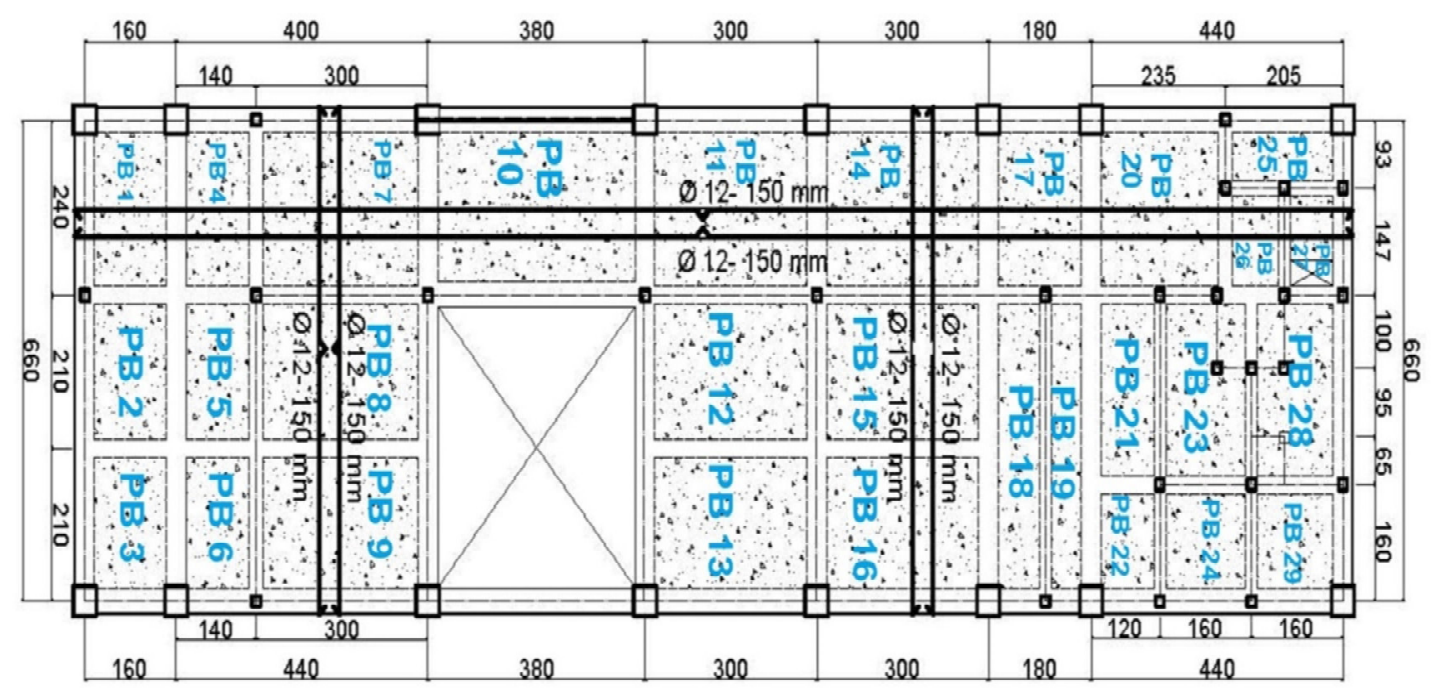

Gambar 3. Penulangan pelat lantai $12 \mathrm{~cm}$

Kedua ukuran pelat tersebut memiliki mutu bahan yang sama baik mutu beton maupun mutu baja. Kuat tekan beton K-250 dan mutu baja fy $=240 \mathrm{Mpa}$. Penulangan pada pelat lantai menggunakan tulangan dua lapis (Lapis atas dan lapis bawah) dengan $\varnothing 12-150 \mathrm{~mm}$, baik untuk tulangan memanjang maupun tulangan melintang. Penulangan pada pelat deck menggunakan tulangan dua lapis dengan Ø 10-150 mm.

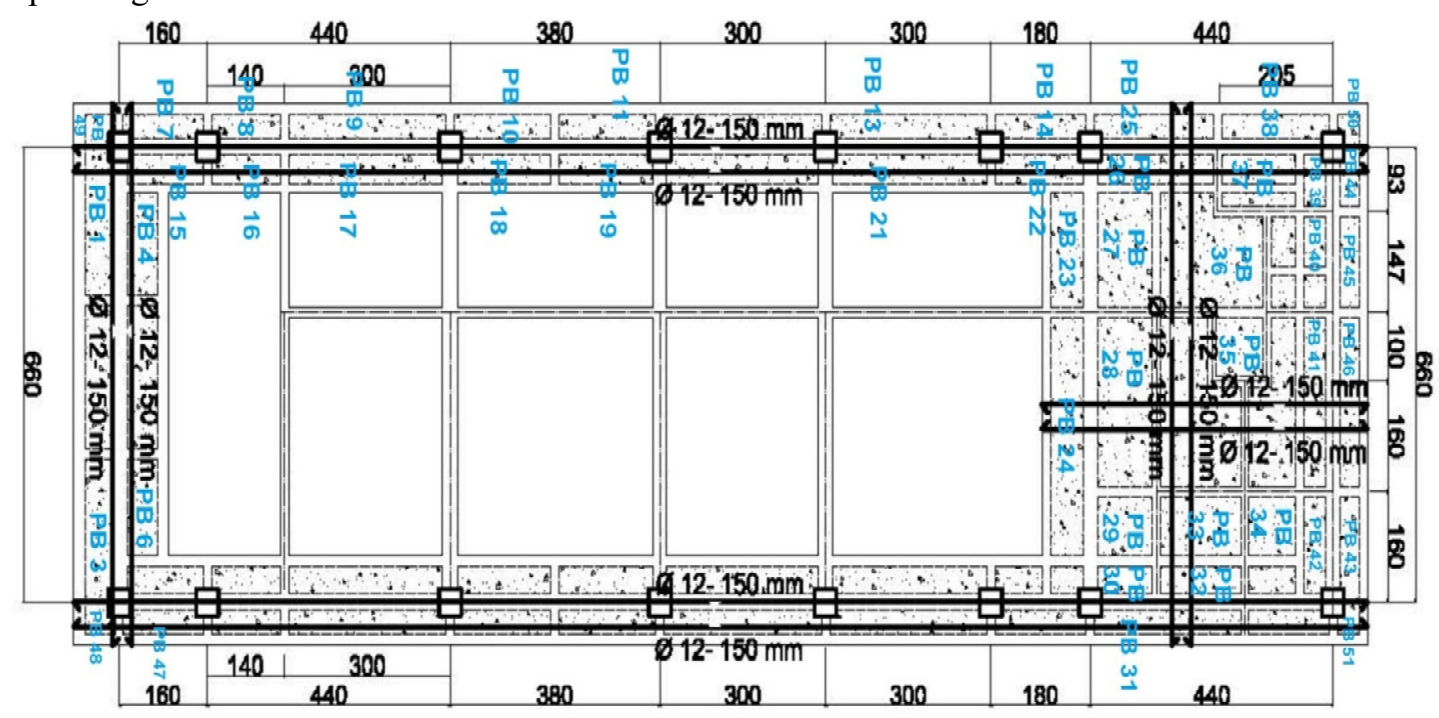

Gambar 4. Penulangan pelat deck $10 \mathrm{~cm}$

TEKNOSIAR Volume 15, No.01, April 2021

p-ISSN 1907-5197 (versi cetak) e-ISSN 2721-2270 (versi online) 


\section{Data Bondek}

Bondek yang digunakan adalah Union Floor Deck W-1000 yang dipasarkan oleh PT. Union Metal, berikut adalah spesifikasi bahannya:

a. Bahan Dasar : Baja High - Tensile

b. Tegangan Leleh Minimum : $560 \mathrm{MPa}$

c. Tebal Lapis Lindung : $220-275 \mathrm{gr} / \mathrm{m}^{2}$

d. Tebal Standar : 0,65 mm, 0,7 mm, $1 \mathrm{~mm}, 1,4 \mathrm{~mm}$

e. Standar Bahan : SNI 07-2053-2006

f. Panjang : maks $12 \mathrm{~m}$

g. Tinggi Gelombang : $50 \mathrm{~mm}$

h. Lebar Efektif : $995 \mathrm{~mm}$

i. Luas dan Momen Inersia Bondek :

Tabel 1. Luas dan momen inersia bondek

\begin{tabular}{ccc}
\hline $\begin{array}{c}\text { Thickness } \\
(\mathrm{mm})\end{array}$ & $\begin{array}{c}\text { Area (As) } \\
\mathrm{mm}^{2}\end{array}$ & $\begin{array}{c}\text { Momen of Inertia } \\
(\text { Isf }) \mathrm{mm}^{4}\end{array}$ \\
\hline 0,65 & 796,33 & 391911,92 \\
\hline 0,70 & 857,59 & 422063,58 \\
\hline 1,00 & 1225,13 & 602999,87 \\
\hline (Sumber : Brosur floor deck $W-1000$ PT. Union Metal)
\end{tabular}

\section{Analisis Pelat Beton Konvensional}

Data pelat konvensional yang telah diperoleh dari gambar kerja serta data pendukung lainnya dari pihak pemilik gedung pada tahap ini akan dilakukan analisis kembali, untuk memperoleh beban yang bekerja dan momen kapasitas yang terpasang pada pelat lantai Gedung Puskesmas Kota Ende tersebut. Agar selanjutnya dapat digunakan sebagai dasar acuan menganalisis pelat beton bondek.

\section{a. Momen Kapasitas Terpasang (MU Ada)}

Penulangan pada pelat lantai tebal $12 \mathrm{~cm}$ dan pelat deck tebal $10 \mathrm{~cm}$ menggunakan tulangan dua lapis (lapis atas dan lapis bawah), masing-masing berdiameter $\varnothing 12-150 \mathrm{~mm}$ dan $\varnothing 10-150 \mathrm{~mm}$ baik untuk tulangan tekan maupun tulangan tarik. Sehingga kapasitas momen yang terpasang $\left(\mathrm{MU}_{\mathrm{Ada}}\right)$ untuk tulangan tekan dan tulangan tarik melalui langkah perhitungan serupa memiliki nilai yang sama, seperti terangkum pada tabel 2 dan tabel 3 berikut ini :

Tabel 2. Rekapitulasi momen ultimit ada (MU ${ }_{\text {ada }}$ ) pelat tipe I

\begin{tabular}{clcc}
\hline No & \multicolumn{1}{c}{ Jenis Tulangan } & $\begin{array}{c}\text { Dimensi } \\
\text { Tulangan }\end{array}$ & $\begin{array}{c}\mathrm{Mu}_{\mathrm{Ada}} \\
(\mathrm{kNm})\end{array}$ \\
\hline 1. & Tulangan tekan arah $\mathrm{x}$ & $\varnothing 12-150$ & 14,466 \\
\hline 2. & Tulangan tekan arah y & $\varnothing 12-150$ & 14,466 \\
\hline 3. & Tulangan tarik arah x & $\varnothing 12-150$ & 14,466 \\
\hline 4. & Tulangan tarik arah y & $\varnothing 12-150$ & 14,466 \\
\hline & & &
\end{tabular}

TEKNOSIAR Volume 15, No.01, April 2021

p-ISSN 1907-5197 (versi cetak) e-ISSN 2721-2270 (versi online) 
Maria Alfiani Weli1, Yohanes Laka Suku, Veronika Miana Radja

Analisis Penggunaan Pelat Beton Bondek Pada Struktur Lantai Gedung Puskesmas Kota Ende

Tabel 3. Rekapitulasi momen ultimit ada (MUAda) pelat tipe II

\begin{tabular}{llcl}
\hline No & Jenis Tulangan & $\begin{array}{c}\text { Dimensi } \\
\text { Tulangan }\end{array}$ & $\begin{array}{c}\text { MU Ada } \\
(\mathrm{kNm})\end{array}$ \\
\hline 1. & Tulangan tekan arah $\mathrm{x}$ & $\varnothing 10-150$ & 8,076 \\
\hline 2. & Tulangan tekan arah y & $\varnothing 10-150$ & 8,076 \\
\hline 3. & Tulangan tarik arah x & $\varnothing 10-150$ & 8,076 \\
\hline 4. & Tulangan tarik arah y & $\varnothing 10-150$ & 8,076 \\
\hline \multicolumn{5}{c}{ (Sumber : Data perhitungan excel) }
\end{tabular}

Berdasarkan tabel 2 dan tabel 3 diperoleh momen kapasitas yang terpasang pada pelat lantai $12 \mathrm{~cm}$ dan pelat deck tebal $10 \mathrm{~cm}$ berturut-turut sebesar $14,466 \mathrm{kNm}$ dan $8,076 \mathrm{kNm}$.

\section{b. Momen Lentur yang Bekerja (MUPerlu)}

Pelat lantai beton konvensional harus mampu menahan beban lentur maksimum yang terjadi. Perbandingan beban lentur maksimum yang terjadi pada pelat dua arah dengan kapasitas beban ada pelat konvensional dapat dilihat pada tabel 4 dan tabel 5 .

TEKNOSIAR Volume 15, No.01, April 2021

p-ISSN 1907-5197 (versi cetak) e-ISSN 2721-2270 (versi online) 
Maria Alfiani Weli1, Yohanes Laka Suku, Veronika Miana Radja

Analisis Penggunaan Pelat Beton Bondek Pada Struktur Lantai Gedung Puskesmas Kota Ende

Tabel 4. Perbandingan MU Ada dan MUPerlu pelat dua arah pada pelat tipe I

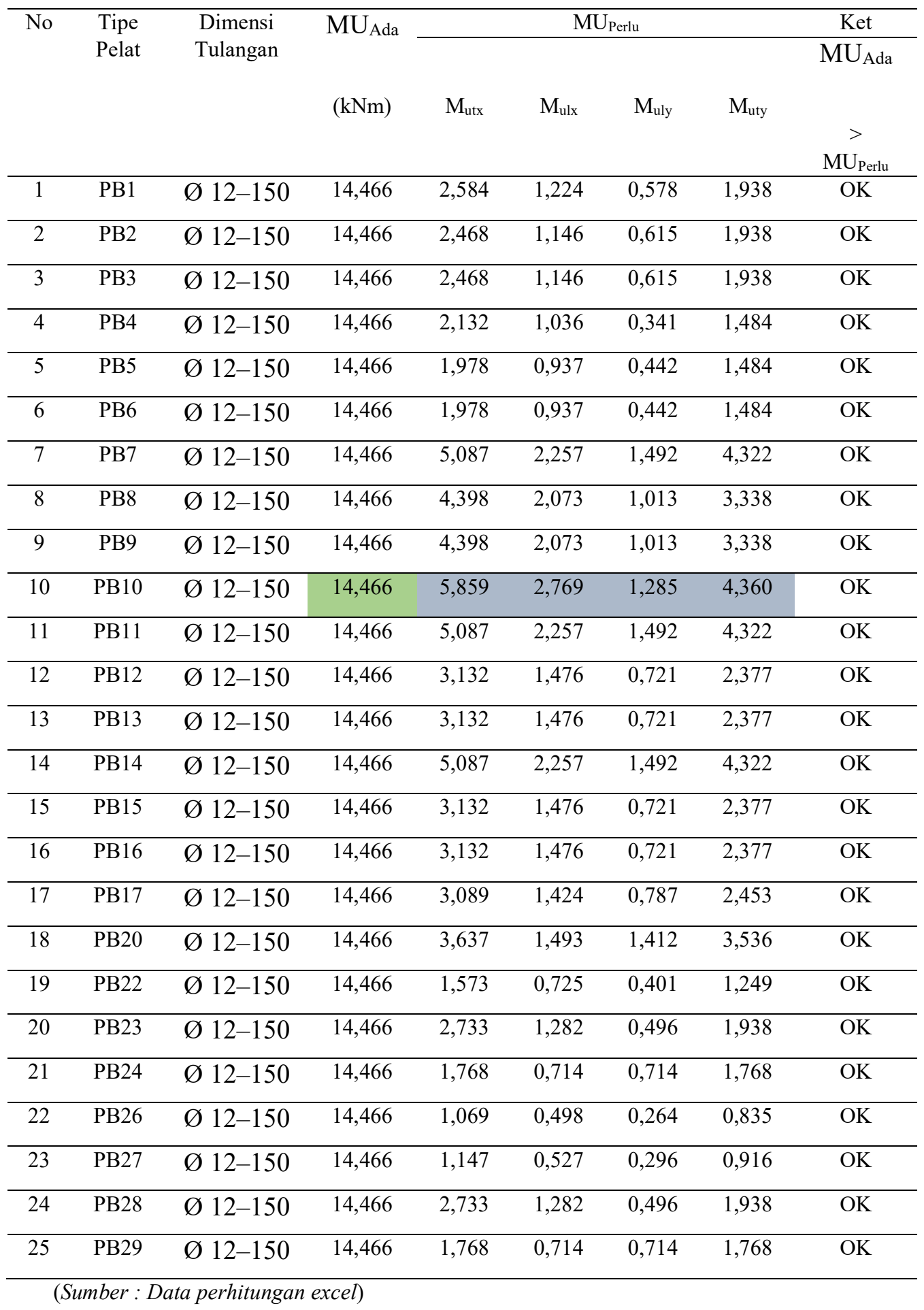

TEKNOSIAR Volume 15, No.01, April 2021

p-ISSN 1907-5197 (versi cetak) e-ISSN 2721-2270 (versi online) 
Maria Alfiani Weli1, Yohanes Laka Suku, Veronika Miana Radja

Analisis Penggunaan Pelat Beton Bondek Pada Struktur Lantai Gedung Puskesmas Kota Ende

Tabel 5. Perbandingan MUAda dan MUPerlu pelat satu arah pada pelat tipe II

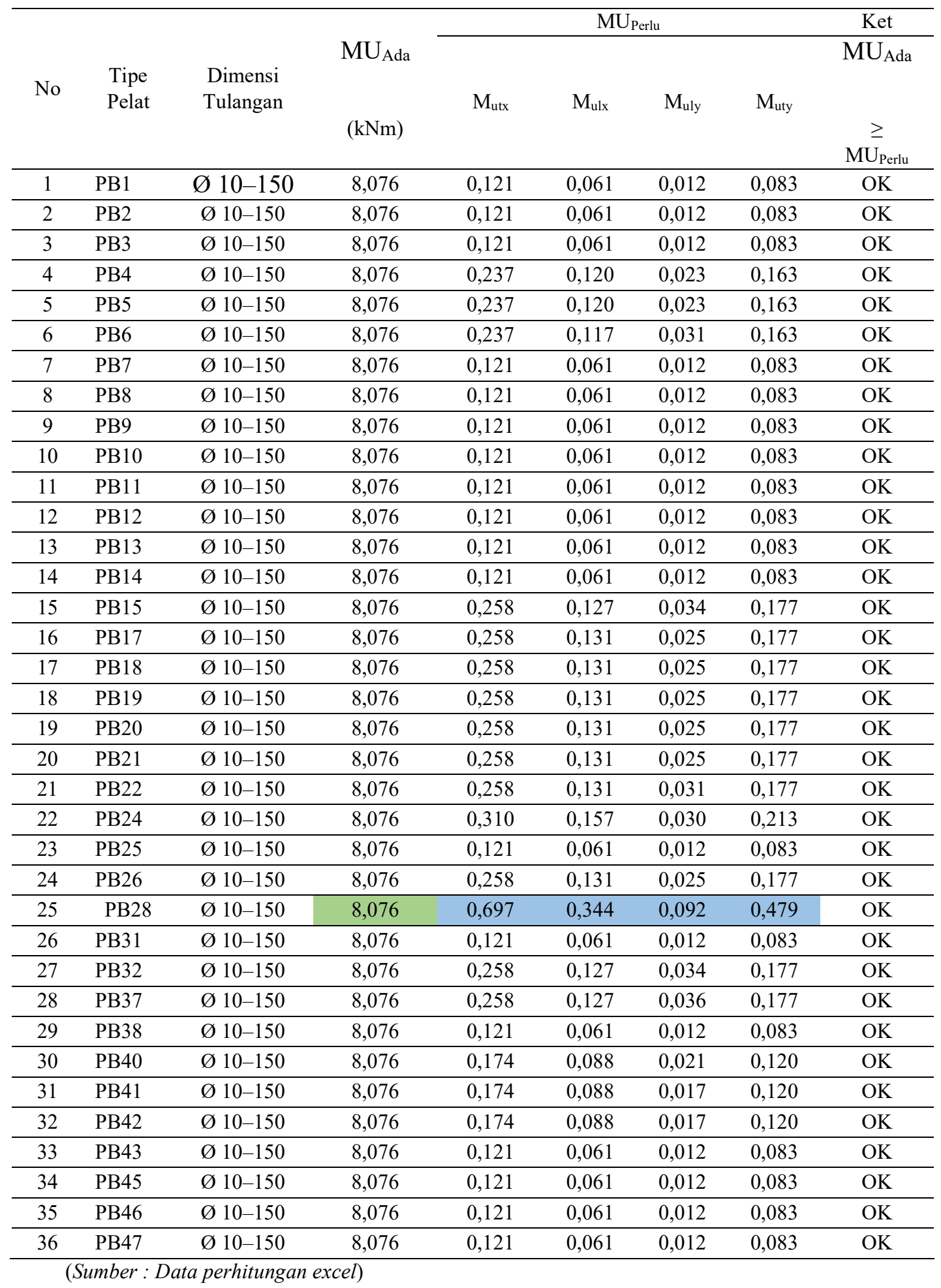

TEKNOSIAR Volume 15, No.01, April 2021

p-ISSN 1907-5197 (versi cetak) e-ISSN 2721-2270 (versi online) 
Dari tabel 4 diperoleh momen lentur maksimum terdapat pada pelat bagian 10 (PB10), dengan momen lentur tumpuan dan lapangan arah x dan y sebesar $\mathrm{M}_{\mathrm{utx}}=5,859 \mathrm{kNm}, \mathrm{M}_{\mathrm{uty}}=4,360 \mathrm{kNm}$, $\mathrm{M}_{\mathrm{ulx}}=2,769 \mathrm{kNm}$, dan $\mathrm{M}_{\mathrm{uly}}=1,285 \mathrm{kNm}$. Beban lentur maksimum yang terjadi lebih kecil dari kapasitas ada pelat konvensional sebesar $14,466 \mathrm{kNm}$. Artinya pelat konvensional tebal $12 \mathrm{~cm}$ dengan dimensi tulangan Ø 12-150 mampu memikul beban yang bekerja, sehingga dinyatakan aman.

Berdasarkan tabel 5 diperoleh momen lentur maksimum terdapat pada pelat bagian 24 (PB24), dengan momen lentur tumpuan dan lapangan arah x dan y sebesar $\mathrm{M}_{\mathrm{utx}}=3,272 \mathrm{kNm}, \mathrm{M}_{\mathrm{uty}}=2,247$ $\mathrm{kNm}, \mathrm{M}_{\mathrm{ulx}}=1,656 \mathrm{kNm}$, dan $\mathrm{M}_{\text {uly }}=0,315 \mathrm{kNm}$. Beban lentur maksimum yang terjadi lebih kecil dari kapasitas ada pelat konvensional sebesar $8,076 \mathrm{kNm}$. Artinya pelat konvensional tebal $10 \mathrm{~cm}$ dengan dimensi tulangan Ø 10-150 mampu memikul beban yang bekerja, sehingga dinyatakan aman.

\section{Analisis Pelat Beton Bondek}

Setelah memperoleh nilai momen kapasitas yang terpasang dan momen lentur maksimum yang bekerja pada struktur pelat lantai, selanjutnya pada tahap ini akan dilakukan analisis perhitungan pelat lantai menggunakan bondek sebagai pengganti tulangan tarik. Analisis perhitungan dilakukan berdasarkan American National Standards Institute C-2011 For Composite Steel Floor Deck-Slabs, dan menggunakan tiga ketebalan bondek Union Floor Deck W-1000 yang berbeda dari PT. Union Metal untuk kedua pelat. Pada tahap ini perhitungan yang dilampirkan merupakan analisis pelat lantai dengan tebal $12 \mathrm{~cm}$ sedangkan untuk pelat deck $10 \mathrm{~cm}$ dapat dilihat hasilnya pada tabel 6.

Diketahui :

Momen Ultimit $\left(\mathrm{MU}_{\text {Ada }}\right)=14,466 \mathrm{kNm}$

Tebal Bondek $\quad=0,65 \mathrm{~mm}$

As $\quad=796,33 \mathrm{~mm}^{2}$

Tinggi gelombang $\quad=50 \mathrm{~mm}$

$\mathrm{b} \quad=995 \mathrm{~mm}$

fy $\quad=560 \mathrm{Mpa}$

f'c $\quad=21,75 \mathrm{Mpa}$

Es $\quad=203.000 \mathrm{Mpa}$

$\mathrm{Wc} \quad=2400 \mathrm{Kg} / \mathrm{m}^{3}$

Berdasarkan langkah perhitungan yang telah dilalui, pelat $12 \mathrm{~cm}$ dianalisis menggunakan bondek tebal $0,65 \mathrm{~mm}$ sebagai tulangan tarik, diperoleh momen kapasitas ada pelat beton bondek sebesar $25,35 \mathrm{kNm}$. Selain menggunakan tebal bondek $0,65 \mathrm{~mm}$, juga dianalisis menggunakan bondek tebal $0,70 \mathrm{~mm}$ dan $1,00 \mathrm{~mm}$. hasil perhitungannya dapat dilihat pada tabel 6 .

Dari tabel 6 diperoleh momen nominal lentur yang diperoleh dari pelat lantai $12 \mathrm{~cm}$ dan pelat deck $10 \mathrm{~cm}$ di desain menggunakan bondek dengan ketebalan $0,65 \mathrm{~mm}, 0,70 \mathrm{~mm}$ dan $1,00 \mathrm{~mm}$ cukup kuat dan memenuhi syarat lebih besar dari momen nominal pelat konvensional. Sehingga pada tahap ini masih dapat dilakukan kembali analisis desain pelat bondek melalui langkah perhitungan yang sama untuk mendapatkan dimensi penampang pelat yang lebih ekonomis dengan tetap memperhatikan beban yang bekerja pada pelat serta kekuatan strukturnya.

TEKNOSIAR Volume 15, No.01, April 2021

p-ISSN 1907-5197 (versi cetak) e-ISSN 2721-2270 (versi online) 
Tabel 6. Rekapitulasi perhitungan analisis bondek dari pelat tipe I

\begin{tabular}{|c|c|c|c|c|c|c|}
\hline \multirow{3}{*}{ Perhitungan } & \multicolumn{3}{|c|}{ Pelat Lantai $12 \mathrm{~cm}$} & \multicolumn{3}{|c|}{ Pelat Deck $10 \mathrm{~cm}$} \\
\hline & \multicolumn{3}{|c|}{$\begin{array}{c}\text { Ketebalan Bondek } \\
(\mathrm{mm})\end{array}$} & \multicolumn{3}{|c|}{$\begin{array}{c}\text { Ketebalan Bondek } \\
(\mathrm{mm})\end{array}$} \\
\hline & 0,65 & $\mathbf{0 , 7 0}$ & 1,00 & 0,65 & $\mathbf{0 , 7 0}$ & 1,00 \\
\hline $\mathrm{h}(\mathrm{cm})$ & 12 & 12 & 12 & 10 & 10 & 10 \\
\hline $\mathrm{h}(\mathrm{mm})$ & 120 & 120 & 120 & 100 & 100 & 100 \\
\hline As (mm2) & 796,33 & 857,59 & 1225,13 & 796,33 & 857,59 & 1225,13 \\
\hline $\mathrm{Ix}(\mathrm{mm} 4)$ & 391911,92 & 422063,58 & 602999,87 & 391911,92 & 422063,58 & 602999,87 \\
\hline T. gel (mm) & 50 & 50 & 50 & 50 & 50 & 50 \\
\hline $\mathrm{d}(\mathrm{mm})$ & 95 & 95 & 95 & 75 & 75 & 75 \\
\hline $\mathrm{B}(\mathrm{mm})$ & 995 & 995 & 995 & 995 & 995 & 995 \\
\hline hc (mm) & 70 & 70 & 70 & 50 & 50 & 50 \\
\hline $\mathrm{f}^{\prime c}(\mathrm{Mpa})$ & 20,75 & 20,75 & 20,75 & 20,75 & 20,75 & 20,75 \\
\hline fy (Mpa) & 560 & 560 & 560 & 560 & 560 & 560 \\
\hline $\mathrm{Wc}(\mathrm{Kg} / \mathrm{m} 3)$ & 2400 & 2400 & 2400 & 2400 & 2400 & 2400 \\
\hline Es (Mpa) & 203000 & 203000 & 203000 & 203000 & 203000 & 203000 \\
\hline Ec (Mpa) & 23030,023 & 23030,023 & 23030,023 & 23030,023 & 23030,023 & 23030,023 \\
\hline $\mathrm{n}$ & 8,815 & 8,815 & 8,815 & 8,815 & 8,815 & 8,815 \\
\hline$\rho$ & 0,008 & 0,009 & 0,013 & 0,011 & 0,011 & 0,016 \\
\hline Ycc (mm) & 30,23 & 31,15 & 35,84 & 26,23 & 27,00 & 30,93 \\
\hline Ycs (mm) & 64,77 & 63,85 & 59,16 & 48,77 & 48,00 & 44,07 \\
\hline Ic (mm4) & 4772114,34 & 5055603,86 & 6623063,58 & 2965032,58 & 3138564,05 & 4095775,38 \\
\hline My (kNm) & 29,77 & 31,86 & 44,07 & 22,51 & 24,08 & 33,21 \\
\hline$\varnothing$ & 0,85 & 0,85 & 0,85 & 0,85 & 0,85 & 0,85 \\
\hline \multirow[t]{2}{*}{$\begin{array}{l}\text { MUAda PB } \\
(\mathrm{kNm})\end{array}$} & 25,35 & 27,084 & 37,458 & 19,132 & 20,467 & 28,226 \\
\hline & $>$ & $>$ & $>$ & $>$ & $>$ & $>$ \\
\hline $\begin{array}{c}\text { MUAda PK } \\
(\mathrm{kNm})\end{array}$ & 14,466 & 14,466 & 14,466 & 8,076 & 8,076 & 8,076 \\
\hline $\begin{array}{c}\text { Mu Perlu } \\
(\mathrm{kNm})\end{array}$ & 5,859 & 5,859 & 5,859 & 3,272 & 3,272 & 3,272 \\
\hline
\end{tabular}

TEKNOSIAR Volume 15, No.01, April 2021

p-ISSN 1907-5197 (versi cetak) e-ISSN 2721-2270 (versi online) 


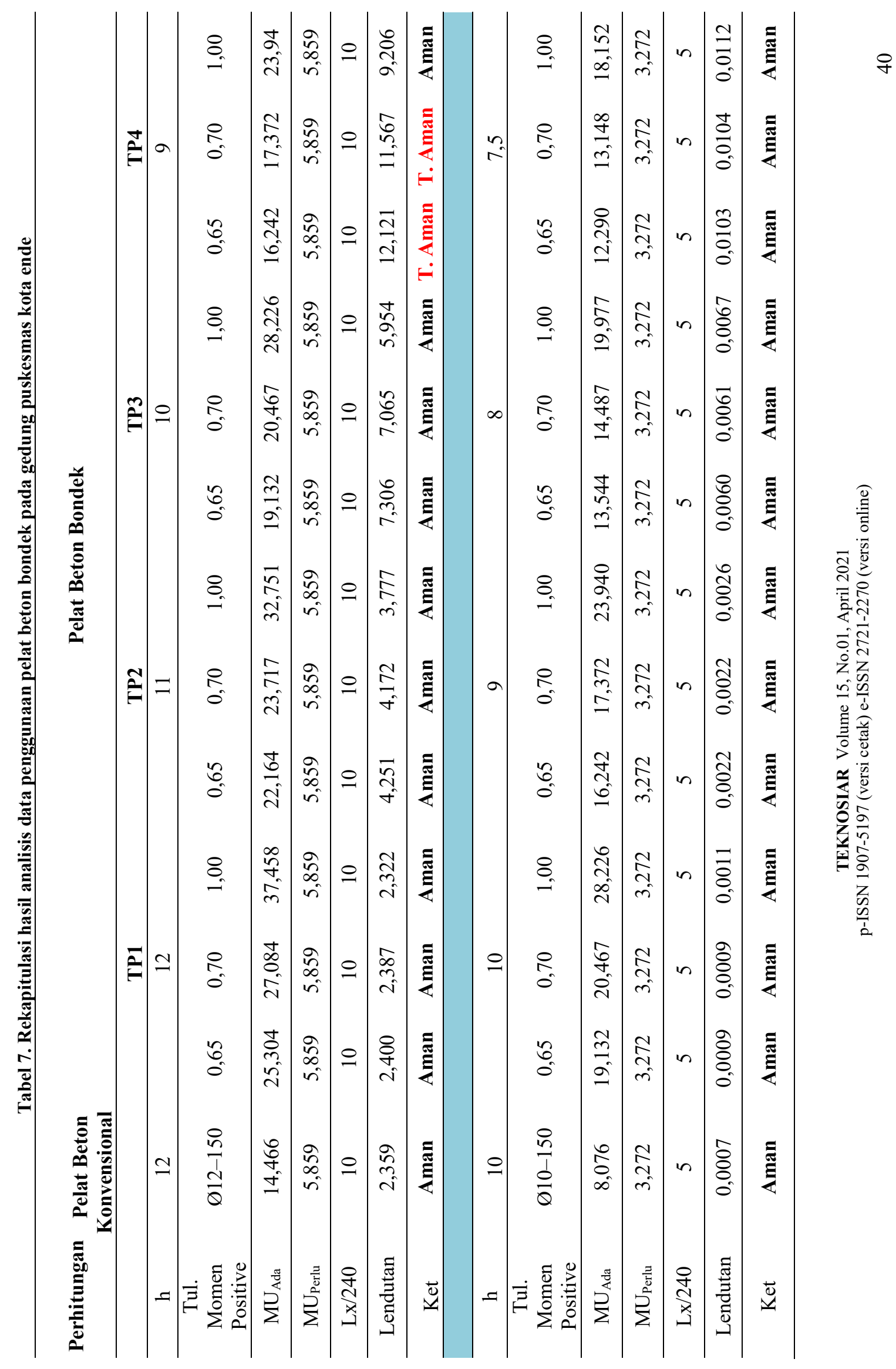




\section{Maria Alfiani Weli1, Yohanes Laka Suku, Veronika Miana Radja \\ Analisis Penggunaan Pelat Beton Bondek Pada Struktur Lantai Gedung Puskesmas Kota Ende}

Berdasarkan tabel 7 dari hasil analisis data diperoleh 22 pelat dalam keadaan aman, karena momen kapasitas ada pelat bondek lebih besar dari momen kapasitas pelat konvensional yang terpasang juga lebih besar dari momen lentur maksimum yang bekerja pada pelat. Selain itu lendutan yang terjadi memenuhi syarat batas lendutan yang diijinkan yaitu Lx/240 $=10 \mathrm{~mm}$. Sedangkan terdapat 2 pelat dalam keadaan tidak aman pada pelat ukuran $12 \mathrm{~cm}$, yang dianalisis menggunakan pelat berukuran lebih kecil yaitu $9 \mathrm{~cm}$ dengan ketebalan bondek $0,65 \mathrm{~mm}$ dan $0,70 \mathrm{~mm}$. Kedua pelat tersebut memiliki momen kapasitas ada lebih besar dari momen kapasitas yang terpasang pada pelat konvensional dan juga lebih besar dari momen lentur maksimum yang bekerja. Namun lendutan yang terjadi pada pelat berukuran $9 \mathrm{~cm}$ dengan bondek $0,65 \mathrm{~mm}$ sebesar $12,121 \mathrm{~mm}$ dan pelat berukuran $9 \mathrm{~cm}$ dengan bondek $0,70 \mathrm{~mm}$ sebesar $11,567 \mathrm{~mm}$, yang mana keduanya tidak memenuhi syarat batas lendutan yang diijinkan yaitu $\mathrm{Lx} / 240=5 \mathrm{~mm}$, sehingga dinyatakan tidak aman.

\section{KESIMPULAN}

Berdasarkan hasil analisis pelat beton bertulang konvensional yang telah dikerjakan dan dianalisis kembali dengan menggunakan pelat bondek, sebagai pengganti tulangan momen positif sesuai data pelat beton bertulang konvensional yang ada, diperoleh kesimpulan sebagai berikut :

a. Pelat beton bertulang konvensional yang telah dikerjakan dengan dua ukuran ketebalan berbeda yaitu $12 \mathrm{~cm}$ untuk struktur pelat lantai dua dan $10 \mathrm{~cm}$ untuk pelat deck, samasama mampu memikul momen lentur maksimum yang bekerja pada kedua pelat atau $\mathrm{MU}_{\text {Ada }}>$ MUPerlu.

b. Dari analisis perhitungan pelat beton menggunakan bondek sebagai pengganti tulangan momen positif pada Gedung Puskesmas Kota Ende, diperoleh :

1. Kapasitas momen ada pada pelat yang menggunakan bondek tipe $\mathrm{W}-1000$ dengan ketebalan 0,65 mm, 0,70 $\mathrm{mm}$ dan 1,00 mm lebih besar dari kapasitas momen pelat beton bertulang konvensional yang terpasang atau $\mathrm{MU}_{\mathrm{Ada}}$ pelat bondek $>\mathrm{MU}_{\mathrm{Ada}}$ pelat konvensional.

2. Lendutan yang terjadi pada pelat beton konvensional dalam kondisi aman karena memenuhi syarat batas maksimum lendutan yang diijinkan yaitu $\mathrm{Lx} / 240=10 \mathrm{~mm}$ (untuk pelat $12 \mathrm{~cm}$ ) dan $\mathrm{Lx} / 240=5 \mathrm{~mm}$ (untuk pelat $10 \mathrm{~cm}$ ).

3. Lendutan yang terjadi pada pelat beton bondek semakin kecil ketika tebal bondek semakin besar. Dari hasil analisis diperoleh dua puluh dua (22) pelat dalam kondisi aman karena memenuhi syarat batas lendutan maksimum yang diijinkan. Sedangkan dua (2) pelat dalam keadaan tidak aman karena tidak memenuhi syarat batas lendutan maksimum yang diijinkan.

\section{DAFTAR PUSTAKA}

ANSI, 2011. American National Standards Institute Accredited Standards Developer For Composite Steel Floor Deck - Slabs. USA: Steel Deck Institute.

Andi TU. 2012. Perbandingan Biaya Pelaksanaan Pelat Beton Menggunakan Boundeck dan Pelat Konvensional pada Gedung Graha Suraco [Jurnal]. Makassar : Universitas Hasanuddin.

Asroni, A. 2017. Teori dan Desain Balok Plat Beton Bertulang Berdasarkan SNI 2847-2013. Surakarta : Muhammadiyah University Press.

BSN, 2013. Beban Minimum untuk Perancangan Bangunan Gedung dan Struktur Lain (SNI 2847: 2013) Jakarta: Badan Standardisasi Indonesia (BSN).

BSN, 2013. Persyaratan Beton Struktural untuk Bangunan Gedung (SNI 2847: 2013) Jakarta: Badan Standardisasi Indonesia (BSN).

TEKNOSIAR Volume 15, No.01, April 2021

p-ISSN $1907-5197$ (versi cetak) e-ISSN 2721-2270 (versi online) 
Maria Alfiani Weli1, Yohanes Laka Suku, Veronika Miana Radja

Analisis Penggunaan Pelat Beton Bondek Pada Struktur Lantai Gedung Puskesmas Kota Ende

Dewi SU. \& Kusmila W. 2018. Analisis Struktur Pelat Lantai Beton Konvensional dan Pelat Lantai Bondek (Gedung Kuliah Fakultas Tarbiyah dan Keguruan Uin Raden Intan Lampung). Tapak. 8(1):120-124.

Fastaria R. \& Putri YE. 2014. Analisa Perbandingan Metode Halfslab dan Plat Komposit Bondek Pekerjaan Struktur Plat Lantai Proyek Pembangunan Apartement De Papilio Tamansari Surabaya. Jurnal Teknik Pomits. 3(2):43.

Kembuan P., Wallah PSE. \& Dapas OS. 2018. Desain Praktis Pelat Konvensional Dua Arah Beton Bertulang. Jurnal Sipil Statik. 6(9):705-710.

Muyassar R. 2017. Analisis Perbandingan Biaya Pembuatan Pelat Beton dengan Metode Pelat Bondek dan Pelat Konvensional pada Konstruksi Gedung Bertingkat (Studi Kasus : Pembangunan Ruko di Binjai ) [Jurnal]. Medan : Universitas Sumatera Utara.

Pottu YE. 2014. Penerapan Rekayasa Nilai (Value Engineering) pada Proyek Pembangunan Gedung Poliklinik dan Kedokteran Hewan Universitas Brawijaya Malang [Skripsi]. Malang : Institut Teknologi Nasional Malang.

Sholehah S. \& SumarningsihT. Tanpa Tahun. Perbandingan Biaya Pelaksanaan Pelat Beton Bondek Dengan Pelat Konvensional Pada Gedung Hotel Bhayangkara Yogyakarta. [Jurnal]. Yogyakarta : Universitas Islam Indonesia.

Suku, YL \& Je, K. 2020, Modeling and Analysis of the Effect of Holes in Reinforced Concrete Column Structures. Journal of the Civil Engineering Forum 6 (1), 27-36.

Winter, George, Arthur H. Nilson. 1993. Perencanaan Struktur Beton Bertulang (Tim Editor dan Penerjemah Institut Teknologi Bandung). Jakarta : PT. Pradnya Paramita.

TEKNOSIAR Volume 15, No.01, April 2021

p-ISSN 1907-5197 (versi cetak) e-ISSN 2721-2270 (versi online) 